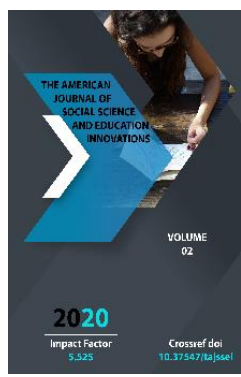

\title{
The Styles Of Using Folk Games In Development Of Healthy Lifestyle
}

\author{
Salimjon Valievich Yuldashev \\ Doctor Of Philosophy (PhD), Fergana State University, Fergana, Uzbekistan
}

Copyright: Original content from this work may be used under the terms of the creative commons attributes 4.0 licence.

\section{ABSTRACT}

One of the factors in the formation and development and a healthy lifestyle of young people, folk games' history and scientific analysis and methods of using children's game are all described in this article. Furthermore, samples and recommendations from games that develop the healthy lifestyle of youth.

\section{KEYWORDS}

Healthy lifestyle, public policy, decree, decision, game, competition, strong, agile, active, intelligent, witty, collaborative, ideological, political, mental, moral work, aesthetic care, find color, tandoor ready, lappak, porsin-pors, telling the riddles, flew, a greeting game, pair or odd, who said.

\section{INTRODUCTION}

The main aim of state of youth policy in the Republic of Uzbekistan is considered as a base for the formation of a healthy lifestyle of young people. In the years of independence, the social-legal foundation of this state policy's problems according to idea of prosperous generation is created.
In particular, the Constitution of the Republic of Uzbekistan, resolutions "On State Youth Policy", "On Public Health", "On Social Protection of Persons with Disabilities", "On the Development of Physical Culture and Sports", "On Guarantees of the Rights of the Child", A number of government resolutions 
and orders on this issue "On measures to ensure the conditions for healthy nutrition of students in educational institutions" were adopted and put into practice.

These Law and legal documents;

- The fulfilment of the rights and freedoms of youth;

- Formation of healthy living culture;

- Creation of a firm system of social protection;

- Formation of a culture of healthy living of young people by increasing the social activity of youth, ensuring the wider fulfilment of their interests.

These issues are considered an important fields of formation youth healthy lifestyle, their scientific-theoretical foundations should be examined by pedagogues, psychologists, historians, biologists, physiologists, political scientists and medical scientists. Moreover, these problem problem requires, first of all, that healthy thinking is the basis for a healthy lifestyle and a culture of healthy living, a new approach to the spiritual education of the younger generation, its study, evaluation and purposeful use of the rich cultural heritage of our people.

\section{MATERIALS AND METHODS}

Information about folk games is given on historical sources, ethnographic materials, archival documents as well as several scientific references, articles, reports.

The research historiography's analysis shows that the ethno-historical features of the population of Central Asia could be interesting to different categories of people who came to this area.
In particular, hundreds of geographerstourists, military personnel, merchants and spies from Central Asia, including the Russian Empire and foreign countries, visited the area and interested in the ethno-cultural and economic life of the population in the 19th and early 20th century. Memories about costumes, rituals, daily life of the local people are written or provided the interesting data in articles and works.

In this case the scientific analysis that are conducted by X. Potanin, A. Middendorf, V.V. Velyaminov-Zernov, A. Shishov, A.P. Khoroshkin, V. Firsov, N.F. Sitnyakovskiy, A.I. Bryanov, A Divaev, A. Kasatkin, A.E. Kushakevich, P.E. Kuznetsovs can be noted. The data about daily lifestyle of Fergana valley and customs, folk games, ulak (the traditional game like a horses' race) gorse caring are provided. Some authors informed about children's game too.

These kinds of works have a zonal and territorial character in this field the works of E.M. Peshereva, V.V. Bartold, N.N. Pantusov should be noted.

The attention to learn the folk games and their territorial and general characters improved during the independence, according to circumstances of historical, ethnographic, archeologic, pedagogical F. Xujayev, G.P. Bogdanov, G. Jahongirov, H. Ismoilov, Mahmud Sattor, I. Jabborov, N.X. Azizov, R. Abdumalikov, K. Abdullaev, Sh. Norkulov, Khushboq Mardonaqul oglu, A. Anarboev, U.I. Islomov, B. Matboboev, K.A. Kraxmal, U. Qoraboev, A.A. Askarov's works the analiysis and researches were conducted about uzbek folk games, and its history, and usage it in the social life, history of children's game and their 
types, to establish moral and national values and the educational significance.

Moreover, popular folk games among the population, in particular, the little information about folk games of Turkistan is also given. For example, in the book of Turkish scientists Bahaiddin Ugel "Turkic culture" it is noteworthy that game of Ulak (kupkari) and its customs, such as horse-racing, girl chasing, hospitality are classified with examples of Turkic people.

\section{ANALYSIS AND RESULTS}

The formation and improvement of folk games are insaperablely connected with economic and domestic life of the population, has subregional, georegional character. in order to rise to degree of national values the folk games have passed the far century examines and experience. Some games saved the characters of created years, others updated and modernized.

The folk games are not only national vales, but also an equipment of bringing up young generation as perfect, strengthen the feeling as an owner of this country, important education on upbringing prosperous generation. The idea "we should realize that when, in what kind of ways and direction should we teach and make them realize national values, customs" [1] is very actual today.

One of the ways of upbringing today's youth, educating as physically, moral prosperous is practicing through folk games.

Every nation's cultural-moral wealth includes folk games too. According to appearing and developing folk games is not extraordinary phenomena, but it is an activity that describes characteristically, specific population's life and aimed activity that is adopted with the law of development of society.

Folk games are an exclusive genre of creativity of nation, it has long centuries old history. In those the social events of any rate of development of society is reflected clearly.

In considering the gradual development of folk games in the process of historical development and the use of these games for educational purposes, special attention should be paid to the specific aspects of each type of folk games. The games were created by the people and figuratively reflected the events and happenings in people's daily lives. It formed their life impressions, observations, experiences and feelings, as well as music and dance. In primitive society, so-called celebrations and religious ceremonies were common. These are peculiar games, competitions, the content of which consists of labor activity, tribal customs, traditions, folklore. In such games, young men had to demonstrate their ability to use weapons, religious customs, songs, and tribal traditions. Dances were also performed in the ceremonies, in which primitive people expressed the events of their lives, their successes and failures, their joys and sorrows.

Exploring the origins of game and art, D.U. Elkonin said, "Primitive people expressed hunting, war events, and other serious activities in games. Playing on the failure of the hunt helped them identify the mistakes they made and the reasons for their failure. "[3]

The games that are being saved from far history became one of the part of their life. Wishes, lifestyle, history of population are reflected in the games [4]. Folk games have a long history like customs and traditions. These 
games as a result of effects of some competitions were modernized, but some of others save the local characters. This proved that leadership according to the components of condition social-psychological, fun, enjoyment, high rate of enthusiasm, inclined to organizing events. Folk games have central position in the system of national values belongs to old stratum of moral heritage. There is no nation that doesn't form its folk game. Person begins realizing outer world. In this process the person makes an imagination about environment with the helping of toys. In Infanthood, childhood, boyhood, adulthood levels the games excusive are considered voluntary type of activity, they objectively do a social-aesthetic, moral, educational function [5]. In particular, "aunt-aunt" game forms the positive property like guest waiting and to say goodbye them, table setting etiquette from their childhood. This is a level of preparation to family for girls.

Folk games looking like just a spending free time with joy if we look it not seriously. But it includes effective ways of upbringing physical and moral harmony. There are a lot of children's game that are based on education. For example, "Lappak", “rising stones", physical and moral educating children the games that are played with the staffs like a rope, ball and stone are plays an important role. National values, human feelings love for human and environment loyalty to traditions of ancestors in games shows that they have spiritual power. Games are mot created spontaneously. They are the result of nation's creativity, and reflected as realizing their own position and career in the world, creating lovely life are ethnographic elements of folk games. Folk games are the most traditional part of caring national and spiritual values. The still available games in holidays, weddings, holiday exhibitions are base of historical genetic circumstances.

Moreover, it should be noted that harmony in children's game, education on the issue being more careful to environment is important factor. During the process of game intelligence, finesse, being quick-witted, fast, bravery, zeal, looking-out, problem solving skills are required. Taking apart in any games is chosen according to voluntary principle. Auditory and traditional methods of educating moved into playground. Spiritual and physical circumstances are formed with games on pupils. Therefore, the perfect person is formed step by step.

If you see a child who imitates outer world and practice, you could know this an ordinary member of the complexed world is trying to get something.[6] The essence of children's toddling relies on bio base, i.e being adult, young generation of a nation passes this proper way differently to others in the process of upbringing. Folk games provide the people with physical strength and intellectual energy. In particular, mostly played by girls, and more common in the areas which handicraft is developed the games such as "find the color", "Lappak", "Gathered stone", "Riddles" (belongs to the things) helped to improve intellectual potential. Mostly, the games which do a function of bringing up child as perfect person makes the generation to improve firstly, the respect of them to their ancestors, and loyalty to heritage of ancestors.

Any kind of game isn't played by one person. Group or team participate in it. Acting and communicate in one team, rules, norm of morality, helping each other, valued principles of humanity, the parts of psychological and 
spiritual are formed during the playing games. In games the norms between people, acquiring the experience of elder ones and practicing them in personal process is appeared. Folk games form and represent national and common mankind values and realize nationality, being loyal to customs and tradition.

The games are mainly played in open air. Not only the games that are outdoor games played in any season make the people energetic and eager to live, but also the body of participant makes immune to any kind of illness. The massive number of positive features of Uzbek folk games function several types of educational purposes.

The games depend on two sides that are winners and losers. But at the end of the game losing the game is a relative phenomenon, losers improve the progression to win next time, winners try to save stably their position. It makes the friendly environment between the children and develops the preparation physically and spiritually. Folk games appeared as one part of process of educationConsequently, they are social and are closely related to work and study. These are the most important features of Uzbek folk games that allow us to analyze their educational potential. We consider the Uzbek folk games together with the whole spiritual culture of the society and as one of the most important means of educating our people, first of all, the youth of our republic.

Most importantly, it inspires love for the national culture, past and present of the Uzbek people, national traditions and art. It also teaches children honesty, generosity, and serves as a means of passing on the experience of adults to children and youth. Forms a conscious attitude to work in boys and girls. It helps them to be strong, agile, energetic, alert, resourceful, cooperative. Among the Uzbek folk games there are many games related to ideological, political, mental, moral labor, aesthetic and physical education. These include color find, tandir pish, lappak, porsin-pors, riddle telling, flew, greeting game, pair-odd, who said where I was, we look.

In our research, it is worth noting that among folk games, children's games are an important factor in educating the harmony between nature and man, to treat nature with care and attention at a time when environmental problems are acute.

The game and the players who play it require qualities such as intelligence, skill, entrepreneurship, agility and agility, courage and bravery, alertness and the ability to make extraordinary decisions.

These qualities testify to the wide range of opportunities for children to develop selfconfidence, moral, aesthetic, spiritual components of education through games. Through play, children not only develop spiritual qualities, but also gradually rise to perfection.

\section{CONCLUSION}

In conclusion, folk games are one of the most convenient and voluntary sources of educating children in the mental, spiritual, moral, aesthetic spirit on the basis of these games, as they are played mainly in the open air as a team.

1. Ethnographic analysis of folk games shows that the folk games of the Fergana Valley have their own local features, strict rules and norms of their organization and 
conduct are developed, and games are mainly based on honesty, agility, vigilance, mastery, respect for rivals, hospitality, tolerance, nationality, regardless of the principles of treating the participants of the game without going beyond the limits of universal values.

2. The use of folk games to enrich the spirituality of the people, purify the psyche of the people, preserve national and spiritual traditions, educational work among young people, the ethnic diversity of the population of this historical and ethnographic region is a key factor in the development of interethnic relations.

The feedback from the study led to the development of the following suggestions and recommendations:

1. It is expedient to expand the scope of scientific research, which comprehensively covers the issues of folk games, their types, history, distribution, regulations, regional features, ethnographic analysis.

2. To pay attention to the promotion and popularization of the existing games, books and articles, documents and materials on the Internet. Achieving the inclusion of the Uzbek folk games in the list of national sports.

3. It would be expedient to preserve and develop national sports, folk games and traditions, which are the cultural heritage of mankind, and to promote healthy physical activity.
1. Karimov I. A. The dream of a harmoniously developed generation. - T .: Sharq, 1998. B.8.

2. Salmonov $A$. The tragic consequences of the religious policy of the Soviet government in Uzbekistan (1917-1991) / Textbook. - T .: Dono., 2019. - B. 47.

3. Yuldasheva R. Educational significance of Uzbek folk games. - T .: 1992.-167 p.

4. Alimova N. The state and process of transformation of silkworm breeding in Uzbekistan (1865-1991). - T .: Dono. 22020. Б. 67.

5. Yuldasheva R. Educational significance of Uzbek folk games. - T .: 1992. - B. 28.

6. Mahsumov S. National games-educational tool // Enlightenment. 2007.- №20. March 10.

7. Valievich, Y.S. (2020). CHILDREN'S GAMES AS AN IMPORTANT FACTOR IN THE UPBRINGING OF A HARMONIOUS GENERATION. European Journal of Research and Reflection in Educational Sciences Vol, 8(9).

8. Mirzarahimov, B. H. (2020). The Tasks Of Tourism In Aesthetic Education: The Harmony Of Historicity And Modernity. The American Journal of Social Science and Education Innovations,2(09), 652-658.

9. Mirzarakhimov, B. Kh. (2019). CULTURE OF TOURISM AS A STRATEGY OF DEVELOPMENT OF BOOKING. In PERSPECTIVE AREAS OF SCIENCE AND TECHNOLOGY DEVELOPMENT (pp. 57-58). 